\title{
The use of whey protein concentrate in management of chronic hepatitis C virus - a pilot study
}

Gamal Elattar1, Zeinab Saleh², Safinaz EL-Shebini², Atif Farrag², Mona Zoheiry', Azza Hassanein", Maged EL-Ghannam ${ }^{1}$, Shendy Shendy ${ }^{1}$, Ehab EL-Dabaa ${ }^{1}$, Nariman Zahran ${ }^{1}$

1Theodor Bilharz Research Institute, Imbaba Giza, Egypt

${ }^{2}$ National Research Center, Cairo, Egypt

Submitted: 19 February 2009

Accepted: 13 June 2009

Arch Med Sci 2010; 6, 5: 748-755

DOI: 10.5114/aoms.2010.17090

Copyright @ 2010 Termedia \& Banach

\section{Abstract}

Introduction: Whey protein contains biologically active ingredients that can prevent and attenuate disease besides being nutritive. The aim of the study was to clarify the effects of oral administration of whey protein on viral load and host defence mechanisms, in particular, phagocytic function of neutrophils, selected immunomodulatory cytokines and serum inflammatory markers, in compensated chronic hepatitis C virus (HCV) patients.

Material and methods: Twenty-seven HCV patients (20 males and 7 females) recruited from the hepatology clinic of the Theodor Bilharz Research Institute (TBRI) were given whey protein concentrate (WPC) twice daily for two months. In addition, 15 age and sex matched healthy participants were included in the study, as a control group. Neutrophil phagocytic activity, serum intercellular adhesion molecule (SICAM), interleukin-2 (IL-2), nitric oxide (NO), as well as HCVRNA levels and routine investigations were determined for patients, before and after WPC supplementation and once for the control group.

Results: There was a significant decrease in viral load and markers of active inflammation, alanine aminotransferase (ALT) and aspartate aminotransferase (AST), while serum albumin, total leucocyte counts and absolute neutrophil counts showed significant elevation accompanied by improvement of neutrophil phagocytic activity after WPC supplementation compared to pre-treated levels. The oral WPC supplementation was well tolerated without any serious adverse events.

Conclusions: Oral supplementation of WPC has promising results as a new therapeutic strategy against HCV and its sequelae by decreasing the viral load and active inflammation as well as improving the synthetic capacity of the liver and the phagocytic function of neutrophils, in these patients.

Key words: whey protein, HCV, inflammatory markers, phagocytic function of neutrophils.

\section{Introduction}

Hepatitis C virus (HCV) is a viral pandemic. About 200 mln individuals worldwide are currently infected with HCV [1]. Egypt has a high seroprevalence for HCV infection that reaches up to $20 \%$ in some rural areas [2].

It has been documented that the HCV genome is genetically very unstable and mutates rapidly, leading to persistent viraemia and chronicity in more than $80 \%$ of cases, despite the strong HCV-specific T-cell mediated immune response [3]. Chronically infected patients often develop

\author{
Corresponding author: \\ Prof. Gamal Elattar MD \\ Theodor Bilharz Research \\ Institute \\ El-Nile St., Warrak El-Hader \\ Imbaba Giza, Egypt \\ P.O.BOX: 30 Imbaba \\ Phone: +202 35407276 \\ E-mail: \\ gamalalattar@yahoo.com
}


progressive liver disease from compensated to decompensated state, cirrhosis, hepatic failure, and hepatocellular carcinoma, making HCV infection the first indication for liver transplantation [4]. Chronic compensated hepatitis patients had relatively normal ammonia tolerance and liver function tests. On the other hand, decompensation was characterized by abnormal ammonia tolerance and liver function tests [5].

The treatment of chronic HCV with interferon alpha (IFN- $\alpha$ ) was initially introduced in 1985 and marked a significant advance [6]. However, the obtained response was not as high as expected initially and combination therapy with pegylated interferon and ribavirin has substantially enhanced its efficacy up to 55\% [7]. In spite of such progress, this bitherapy has numerous side effects such as neutropenia causing associated risk of bacterial infections and sepsis, psychiatric and flu-like symptoms, the existence of non-responders and relapses besides being relatively expensive [8].

Earlier studies showed, in Africa and the Middle East, prevalence of genotype 4 of $C$ virus, which frequently has a poorer response to conventional interferon therapy than other genotypes [9]. Therefore, the need for the intervention of new therapeutic agents, that activate host immunity, is a challenge.

Whey protein concentrate (WPC) demonstrates variable effects in HCV patients by correcting decreased lymphocyte glutathione, found in these patients, in order to activate the cell-mediated immune function [10]. Its biological components, in particular bovine serum albumin, alpha-lactalbumin and lactoferrin, which are cysteine-rich proteins, contribute to its potent antioxidant activity, by aiding in the synthesis of glutathione (GSH), a potent intracellular antioxidant, and demonstrate a range of immune-enhancing properties [11].

This notion is supported, since 1980 , by the observation that normal mice fed on WPC as $20 \%$ of a formula diet exhibited a marked increase in antibody production in response to a $\mathrm{T}$ cell dependent antigen [12]. Moreover, it has been reported that the grade of activity of the liver disease is correlated with the level of GSH. Also, the effect of IFN was observed to be improved by administering agents that restore the decrease of GSH levels [13].

To evaluate the clinical efficacy and safety of non-toxic dietary whey protein in compensated chronic HCV patients, the present study was designed to estimate the serum levels of ICAM-1, IL-2, and NO as well as neutrophil count and its phagocytic activity, liver functions and viral load, before and after oral WPC supplementation, with special emphasis on the statistical comparison between the results of studied groups.

\section{Material and methods}

\section{Subjects}

Twenty-seven patients, with compensated HCV disease (20 males and 7 females), with an age range of 22-60 years and a mean of $42.04 \pm 8.25$ years, were enrolled in the study. Patients were selected from the hepatology clinic of TBRI, Egypt, who came for evaluation of their chronic liver disease (CLD) status between April 2006 and June 2007.

Selection of patients at the time of recruitment into the study was based on: proper history taking, complete clinical examination, routine laboratory investigations, in particular, elevated ALT for a period more than 6 months to determine chronicity, the presence of anti-HCV antibodies (Abs) confirmed by HCV- RNA in serum and screening abdominal ultrasonography.

None of our patients had experienced signs of decompensation such as ascites, jaundice, gastrointestinal bleeding, flapping tremors or encephalopathy. Special groups, including children, patients with CLD other than HCV, patients either having renal dialysis or with transplants and patients who had received IFN treatment, are beyond the scope of this study. Concerning nonspecific drugs for liver disease, mainly silymarin, or similar drugs, the continued administration was permitted if the dose was kept constant during the study period. Given that, all patients enrolled in the study were class A Child-Pugh according to the classification of Pugh et al. in 1973 [14]. A group of 15 healthy subjects selected from the medical staff and matched for age and sex served as the control group. All subjects were informed about the study and written consent was obtained from each one. All procedures are according to the Helsinki Declaration of 1975 as revised in 1983.

\section{Study design}

The study was designed to supplement all patients with WPC twice daily (morning and evening) during meals or within 30 min after meals for 8 weeks. To evaluate the efficacy of whey protein, all investigations were performed before and after supplementation for patients and once for the controls. When treatment was discontinued because of patient request, prior data were included in the study as pre-treated results.

\section{Preparation of whey protein concentrate}

Sweet whey ( $\mathrm{pH}$ 6.0-6.2) was obtained from Ras cheese manufacture, Arab Dairy Co., Kaha, Kalubia, Egypt. Fat and fine curd were removed from the whey by a cream separator (Alfa-Laval Lund, Sweden). Particulated whey protein concentrates were prepared according to Paquin et al. [15] and El- 
Sheikh [16] by ultrafiltration of Ras cheese whey. The gross characteristics of the particulated WPC were determined: total solids (TS) according to AOAC [17]; total protein, fat and $\mathrm{pH}$ according to Ling [18]; lactose according to Barnett and Tawab [19]. After preparation, WPC was packaged immediately in glass bottles and kept in the refrigerator. The ingredients of WPC are presented in Table I.

\section{Assay methods}

The following investigations were performed for all patients immediately before WPC supplementation and at the end of the supplement period (8 weeks) and once for the controls. Reference ranges were provided by each manufacturer.

\section{Routine investigations}

All individuals enrolled in the study were subjected to urine and stool analysis, and an automated haemogram using Celtac MEK 8118 (Nihon Kohden, Japan). Blood smears were stained with Leishman-Giemsa; differential leucocyte counts were performed by counting 300 cells and the absolute number of neutrophils was calculated. PT and PC were done using a fibrin timer (Behring, Germany). Liver function tests were carried out using commercially available kits. $\mathrm{HBsAg}$, anti-HBs Abs and total IgM and IgG Abs for HBcAg were determined using enzyme immunoassay (ELISA) kits (Abbott laboratories, North Chicago, IL), to exclude co-infection with HBV.

Anti-HCV Abs were detected using a third generation ELISA kit (Murex anti-HCV, Version III, Murex Diagnostics, Dartford, England). Serum HCVRNA was determined by a quantitative reversetranscription polymerase chain reaction (RT-PCR). HCV was extracted using acid guanidinium thiocyanate-phenol chloroform single step method [20]. Two pairs of primers in the 5' untranslated region (UTR) were used in the nested reaction as described previously by Matsumoto et al [21]. The sensitivity level of this assay is $50 \mathrm{IU} / \mathrm{ml}$.

\section{Special investigations}

\section{Determination of nitric oxide}

Heparinized blood samples were centrifuged and the plasma collected then filtered through a $1.2 \mu \mathrm{m}$

Table I. Composition of the whey protein concentrate

\begin{tabular}{|lc|}
\hline Ingredients & Content \\
\hline Total solids [\%] & 18.24 \\
\hline Total protein [\%] & 15.08 \\
\hline Lactose [\%] & 1.22 \\
\hline Fat [\%] & 1.05 \\
\hline $\mathrm{PH}$ & 7.08 \\
\hline
\end{tabular}

MultiScreen filter plate (Millipore, Bedford, MA). Plasma NO concentrations were determined using the Griess reaction as described previously by Ding and Rana [22] with the following modification. Six $\mu$ l of plasma were mixed with $135.44 \mu$ of $\mathrm{H}_{2} \mathrm{O}$, $20 \mu$ l of $0.31 \mathrm{M}$ phosphate buffer $(\mathrm{pH} 7.5)$ and $10 \mu \mathrm{l}$ of $0.86 \mathrm{mM}$ nicotine adenine dinucleotide phosphate (Boehringer Mannheim Corp., New York, $\mathrm{NY}), 10 \mu \mathrm{l}$ of $0.11 \mathrm{mM}$ flavin adenine dinucleotide (Sigma) and $10 \mu \mathrm{l}$ of nitrate reductase $(1.0 \mathrm{U} / \mathrm{ml})$ (Boehringer Mannheim Corp.) in individual wells of a 96-well plate. Samples were allowed to incubate for $1 \mathrm{hr}$ at room temperature in the dark. One hundred $\mu \mathrm{l}$ of Griess reagent (1: 1 mixture of $1 \%$ sulfanilamide [Sigma] in 5\% H3PO4 and 0.1\% $\mathrm{N}$-[1-naphthyl] ethylenediamine [Sigma]) was added to each well and plates were incubated for an additional $10 \mathrm{~min}$ at room temperature. Absorbance was measured at $540 \mathrm{~nm}$ using a microplate reader.

\section{Determination of sICAM-1}

Serum ICAM-1 levels were assayed by sandwich ELISA technique (Immunotech, France) according to the manufacturer's instructions. Each sample was assayed in duplicate.

\section{Determination of IL-2}

EDTA anticoagulated samples were used to avoid in vitro production of cytokines because EDTA acts as a chelating agent. IL-2 was performed using a commercially available ELISA kit (Predicta, Human Cytokine Assays).

\section{Nitroblue-tetrazolium test}

Unstimulated nitroblue-tetrazolium test (NBT) test was performed immediately or within $2 \mathrm{~h}$ at $4^{\circ} \mathrm{C}$ using heparinized blood. Briefly, 0.1\% NBT was prepared in PBS by adding $10 \mathrm{mg}$ of NBT powder (Sigma, St Louis) to $100 \mathrm{ml}$ of PBS (pH 7.2) and stirred at room temperature for $1 \mathrm{~h}$. The NBT staining was done for neutrophils after their separation using dextran sedimentation [23] as follows: (i) Equal volumes of $0.1 \%$ NBT solution and cell suspension were mixed and incubated for $30 \mathrm{~min}$ at $37^{\circ} \mathrm{C}$. (ii) The tubes were centrifuged at $250 \times \mathrm{g}$ for $5 \mathrm{~min}$. (iii) Smears were prepared from the pellet and stained after drying with Wright stain, and then scoring cells containing formazan deposits (reduced NBT) was performed by counting 200 neutrophils as described by Baehner and Nathan [24].

\section{Statistical analysis}

Statistical analysis was performed using SPSS version 16 software. Results, presented as mean \pm standard deviation and percentages, were compared using one-way analysis of variance 
(ANOVA) and Scheffé's method for comparisons between groups. The data were considered significant when $p<0.05$. Statistical analysis between pre- and post-WPC intake was performed using the paired $t$ test.

\section{Results}

Twelve patients out of 27 who had started receiving WPC oral supplementation completed the test period ( 8 weeks). The causes of discontinuation among the 15 subjects were: nausea and vomiting in 5 patients, diarrhoea and abdominal discomfort in 2 patients and 8 patients preferred shifting to interferon-based therapy. Hence, after performance of the study, the enrolled subjects were classified into: a pre-treated group of patients (group $A$, $n=27$ ) and a post-treated group (group $B, n=12$ ) in addition to the control group ( $n=15)$.

Routine investigations indicated significant reduction of $\mathrm{PT}, \mathrm{PC} \%$ and total leucocyte counts
(Table II), besides absolute neutrophil counts (Table III), in the patient groups compared to control subjects. Although WPC treatment did not change these parameters, significant improvement of neutrophil phagocytic activity was noticed (Table III).

The HCV-RNA results, presented in Table IV, show a statistically significant reduction comparing group $B$ with $A$. In addition, 2 patients had undetected viraemia after WPC treatment. Results of screening liver function tests pointed to a significant rise of albumin and reduction of ALT and AST in group B. Although albumin was normalized after 8 weeks of treatment with WPC, both enzymes were still significantly higher than normal. As regards the results of parameters of active inflammation, a significant reduction of the 3 parameters (sICAM-1, IL-2 and NO) was recorded in group B. However, after WPC supplementation, all 3 parameters were still significantly higher than control subjects, as shown in Table IV.

Table II. Demographic and clinical, characteristics of different studied groups

\begin{tabular}{|c|c|c|c|}
\hline \multirow[t]{3}{*}{ Parameter } & \multicolumn{3}{|c|}{ Group } \\
\hline & \multirow[t]{2}{*}{ Control group } & \multicolumn{2}{|c|}{ Patients groups } \\
\hline & & Group A & Group B \\
\hline Number of patients & 15 & 27 & 12 \\
\hline Gender: male/female ratio & $3 / 2$ & $2 / 1$ & $3 / 1$ \\
\hline Age [years] & $43.1 \pm 9.7$ & $41.2 \pm 7.3$ & $42.4 \pm 9.3$ \\
\hline Child-Pugh class (A) percentage & 0 & 100 & 100 \\
\hline PT [sec] & $11.7 \pm 0.22$ & $15.1 \pm 2.87^{\star}$ & $14.7 \pm 1.98^{*}$ \\
\hline PC [\%] & $96.2 \pm 3.01$ & $63.9 \pm 17.5^{\star}$ & $62.7 \pm 16.9^{*}$ \\
\hline $\mathrm{Hb}[\mathrm{g} / \mathrm{dl}]$ & $13.52 \pm 1.42$ & $11.05 \pm 1.12$ & $11.2 \pm 2.11$ \\
\hline $\mathrm{RBCs}\left[\times 10^{12} / \mathrm{I}\right]$ & $4.73 \pm 0.67$ & $3.87 \pm 0.52$ & $3.86 \pm 0.63$ \\
\hline Platelet count $\left[\times 10^{9} / 1\right]$ & $268.42 \pm 55.05$ & $165.25 \pm 58.65$ & $166.1 \pm 38.9$ \\
\hline Total leucocytic count $\left[\times 10^{9} / 1\right]$ & $7.7 \pm 1.78$ & $5.22 \pm 1.98^{\star}$ & $6.08 \pm 1.1^{\star}$ \\
\hline
\end{tabular}

Data were expressed as mean \pm SD or as percent value, *statistically significant from the control group. Group A - pretreated group, Group $B$ - post-treated group, $P T$ - prothrombin time, $P C$ - prothrombin concentration, $H b$ - heamoglobin concentration, $R B C S-r e d$ blood cells

Table III. Total leucocytic and absolute neutrophil counts and phagocytic activity in the studied groups

\begin{tabular}{|c|c|c|c|}
\hline \multirow[t]{3}{*}{ Parameter } & \multicolumn{3}{|c|}{ Group } \\
\hline & \multirow{2}{*}{$\begin{array}{l}\text { Control group } \\
\quad(n=15)\end{array}$} & \multicolumn{2}{|c|}{ Patients groups } \\
\hline & & Group A $(n=27)$ & Group B $(n=12)$ \\
\hline Total leucocytic count $\left[\times 10^{9} / 1\right]$ & $7.7 \pm 1.78$ & $5.22 \pm 1.98^{*}$ & $6.08 \pm 1.1^{\star}$ \\
\hline Absolute neutrophil count $\left[\times 10^{9} / 1\right]$ & $3.9 \pm 0.9$ & $1.8 \pm 1.98^{*}$ & $2.1 \pm 0.86^{\star}$ \\
\hline $\begin{array}{l}\text { Percentage of unstimulated NBT+ve } \\
\text { neutrophils [\%] }\end{array}$ & 8.7 & 6.7 & 8.3 \\
\hline $\begin{array}{l}\text { Absolute unstimulated NBT+ve } \\
\text { neutrophils }\left[\times 10^{9} / l\right]\end{array}$ & $0.33 \pm 0.017$ & $0.12 \pm 0.012^{*}$ & $0.17 \pm 0.0094^{\star \#}$ \\
\hline
\end{tabular}

Group A - pretreated group, Group B - post-treated group, NBT +ve-nitroblue tetrazolium positive, *statistically significant from the control group, "statistically significant from the pretreated group 
Table IV. Results of viral load, biochemical and inflammatory markers in studied groups

\begin{tabular}{|c|c|c|c|}
\hline \multirow[t]{3}{*}{ Parameter } & \multicolumn{3}{|c|}{ Group } \\
\hline & \multirow{2}{*}{$\begin{array}{l}\text { Control group } \\
\qquad(n=15)\end{array}$} & \multicolumn{2}{|c|}{ Patients groups } \\
\hline & & Group A $(n=27)$ & Group B $(n=12)$ \\
\hline HCV-RNA [10n copy/ml] & Undetected & $18.7 \times 10^{4}$ & $3.75 \times 10^{4 \#}$ \\
\hline Albumin [g/dl] & $4.4 \pm 0.52$ & $3.1 \pm 0.38^{*}$ & $4.20 \pm 0.32^{\#}$ \\
\hline ALT [IU/I] & $10.1 \pm 1.81$ & $47.5 \pm 7.01^{*}$ & $30.5 \pm 3.34^{\star \#}$ \\
\hline AST [IU/I] & $10.13 \pm 1.08$ & $36 \pm 6.87^{*}$ & $28.9 \pm 5.7^{\star \#}$ \\
\hline sICAM-1 [ng/ml] & $230.0 \pm 11.00$ & $877.3 \pm 335^{*}$ & $555.8 \pm 218.8^{\star \#}$ \\
\hline IL-2 [pg/ml] & $6.9 \pm 1.10$ & $34.6 \pm 1.8^{*}$ & $26.5 \pm 2.6^{\star \#}$ \\
\hline $\mathrm{NO}[\mu \mathrm{mol} / \mathrm{l}]$ & $32.17 \pm 2.19$ & $76.36 \pm 8.11^{*}$ & $54.34 \pm 11.95^{\star \#}$ \\
\hline
\end{tabular}

Data were expressed as mean $\pm S D$ or as (copy $\mathrm{n} / \mathrm{ml})$, "statistically significant from the control group, "\#statistically significant from the pretreated group, P-values refer to paired t-test (before \& after vs. control), Group A - pretreated group, Group B - post-treated group

\section{Discussion}

Conventional hepatitis $C$ therapy focuses on reducing the viral load, while it does nothing to address the ongoing liver damage caused by the virus [25].

In this study we tried to elucidate the efficacy of WPC in treatment of HCV infection. To achieve this goal, the present work monitored the liver status and viral load, in addition to selected immunological and haematological parameters, in compensated chronic HCV patients on comparing the pre- with the post-treated results.

Based on published clinical studies, it has been demonstrated that monitoring viral load during the early phases of treatment may provide early information on the likelihood of a response to antiviral therapy [26]. In the present study when comparing the pre- and post-treated groups (A and B), a virological response (a $50 \%$ or greater decrease in HCV RNA level) was achieved in 8 out of the 12 patients belonging to group B. Of these 8 patients, 2 subjects had undetectable levels of HCV RNA at the end of the test period. It has to be noted that the 4 patients whose viral load did not decline appropriately after the 8-week oral course of WPC had a higher pre-treated level than the other patients. It appears that whey protein administration may be more rapidly effective in the case of a low pre-treated viral load. Higher viral loads would need longer courses.

Conversely, WPC intake for 8 weeks did not have a favourable effect on the serum ALT level, as only 4 out of 12 studied subjects (about 33\%) reached the level of a biochemical response (a $50 \%$ or greater decrease in the serum ALT level). This may be related to the fact that our studied subjects had an ALT baseline only about 4 times the control level. Subsequently, the ALT decline seemed to approach the normal level to a certain extent without fulfilling the biochemical response.
Eventually, however, on comparing pre- to post-treated groups, there was a significant reduction in the viral load and the ALT level.

In agreement with our results, Tanaka et al. [27] has demonstrated in his pilot study among 11 patients having low pre-treated viral loads of HCV, and receiving daily bovine lactoferrin, for 8 weeks, a decrease in HCV-RNA and ALT compared to those having higher pre-treated HCV loads. Conversely, in a study conducted among $17 \mathrm{HCV}$ patients who received $12 \mathrm{~g}$ of whey (Immunocal) twice daily for 12 weeks, preceded and followed by $12 \mathrm{~g}$ of casein protein daily for two weeks and four weeks respectively, no significant changes were noted [7]. These conflicting results may be attributed to the selected criteria of the studied patients, particularly viral load baseline and the HCV genotype prevalence.

Post-treated results revealed that albumin was significantly increased, while, for PT, insignificant improvement was noticed, which may suggest the need for longer oral course duration. The improvement in albumin level, reaching the level of normal control subjects, indicates positive nitrogen balance, which is a good achievement, as malnutrition is a cause of many of the complications of chronic liver disease. We assume that hypoalbuminemia met in our patients was due to decreased hepatic synthesis, not a consequence of losing capacity, as none of our patients suffered from diarrhoea, proteinuria or nutritional disorders.

Whey protein concentrate provides all essential amino acids and is rich in branched-chain amino acids (BCAAs), which are important factors in tissue growth and repair [7]. Leucine, in particular, has been identified as a key amino acid in protein metabolism during the translation-initiation of protein synthesis [28]. Moreover, whey proteins, "fast proteins" do not coagulate under acidic 
conditions. They reach the jejunum quickly after entering the gastrointestinal tract, where the hydrolysis of whey is slow, allowing for greater absorption over the length of the small intestine [13].

Taken together, the above-mentioned properties of whey protein, with correction of malnutrition frequently observed in CLD patients, improves the clinical outcome of these patients.

Earlier studies showed that SICAM-1 is correlated with degree of active inflammation and histopathological activity [29]. Subsequently, it can be considered as a useful marker of hepatocellular necrosis and inflammatory activity in chronic hepatitis and has prognostic significance in cirrhotic patients [30].

The obtained data revealed a significant elevation of SICAM-1, IL-2 and NO levels in diseased groups $A$ and $B$ compared to the control group, while a significant decrease was observed on comparing group B to $A$. In addition, correlation studies showed that SICAM-1 was directly correlated with the viral load in group $A$ and inversely correlated with serum albumin in group $B$. Therefore, a reducing effect of WPC on SICAM-1 and viral load accompanied by improvement of the liver status of HCV patients was recorded, as indicated by increasing serum albumin, considered as a monitor of the synthetic capacity of the liver.

Our findings are consistent with those of Capra et al. [30] and Montalto et al. [31] as regards SICAM-1 after IFN treatment of HCV patients and for IL-2 in other studies [32, 33]. In contrast to our IL-2 results, Zekri et al. [9] reported insignificant changes in serum IL-2 measurements in chronic HCV patients. The authors attributed this finding to the presence of soluble receptor (sIL-2R) binding to IL-2.

The NO increase during the course of HCV infection is explained by Machida et al. [34]. They reported that the viral core and NS3 proteins can stimulate the production of $\mathrm{NO}$ in hepatocytes and $B$ cells through activation of the inducible NO synthase (iNOS) gene. NO causes DNA breaks and enhances DNA mutation and subsequently is correlated with the severity of the disease [35]. $A$ recent study conducted on rats injected with whey protein $(300 \mathrm{mg} / \mathrm{kg}$ ) revealed that alphalactalbumin has a marked suppressive effect on pro-inflammatory cytokine release, particularly IL-6, through an NO-mediated mechanism [36].

Increased susceptibility to recurrent and serious bacterial infections is a common association in CLD [37], which in turn is due to impairment of phagocytic function of neutrophils and natural killer cell activity of lymphocytes among these patients [38]. Data obtained from the present study revealed a significant decrease in total leucocyte, absolute neutrophil and NBT +ve neutrophil counts in diseased groups compared to the control one. On comparing pre- and post-treated groups, a significant increase in number of absolute NBT +ve neutrophils was found in the post-treated group. Considering NBT as an indicator of the phagocytic activity of neutrophils, the present results agree with several studies [39, 40]. Nakamura et al. [38] concluded that phagocytic function of neutrophils was significantly improved by 3 month-BCAA supplementation, although changes of albumin level were insignificant.

Studies on whey protein, in particular its contents of lactoferrin, and alpha-lactalbumin, have demonstrated its ability to activate natural killer (NK) cells and neutrophils by intracellular replenishment of depleted glutathione [13]. Also, lactoferrin has antiviral properties, through its iron chelating properties. Several studies have revealed that hepatitis $C$ inflicts most of its damage by latching onto molecules of iron, resulting in freeradical damage to liver cells. Despite substantial scientific evidence, few physicians implement irondepletion therapy when treating hepatitis C [41].

Meanwhile, neutrophils have been shown by RTPCR to be among the extra-hepatic sites of HCV replication [42]. Hence, the significant improvement of NBT +ve cells in the post-treated group and the increased absolute neutrophil count, although not to a significant level, recorded in this work indicate a beneficial effect of WPC mainly on the qualitative and to a lesser extent on the quantitative status of neutrophils among HCV patients.

Finally, our present trial left many unanswered questions for future studies, including optimum dose, duration, and the potential effects of combining WPC supplementation with conventional treatment. In addition, the effects of whey protein administration and its long-term use on prognosis of patients with high pre-treated viral loads, advanced stages of liver disease and in hepatocarcinogenesis remain to be investigated in the future.

In conclusion, WPC supplementation showed promising results among compensated hepatitis $C$ virus patients. It has a viral load reducing effect, accompanied by normalization of serum albumin and improvement of phagocytic function of neutrophils, at the end of an 8-week oral course. These responses were paralleled with a significant decrease in serum levels of ALT, ICAM-1, IL-2 and NO. Presumably, WPC administration provides nutrition which could positively affect the prognosis of the patients. Also, it is well tolerated and shows no side effects like those of conventional therapy. Hence, we recommend trying this supplementation as an adjuvant to interferon therapy or as an alternative for non-responders. Prospective studies are needed to enlighten these postulations. 


\section{Acknowledgments}

The authors are grateful for the support of the Theodor Bilharz Research Institute (TBRI) and the National Research Centre (NRC). We are grateful to Dr. Hoda Abou Taleb for her sincere help and much effort in the statistical analysis of this study.

\section{References}

1. Dixit NM, Layden-Almer JE, Layden TJ, Perelson AS. Modelling how ribavirin improves interferon response rates in hepatitis C virus infection. Nature 2004; 432: 922-4.

2. Frank C, Mohamed MK, Strickland GT, et al. The role of parenteral antischistosomal therapy in the spread of hepatitis C virus in Egypt. Lancet 2000; 355: 887-91.

3. El-Bassiouny AEl. Cytokines adhesion molecules interaction in chronic HCV infection. The XIV Annual Conference of Egyptian Society of Laboratory Medicine (Abstract). 2003.

4. Gjertsen H, Weiland O, Oksanen A, Soderdahl G, Broome $\mathrm{U}$, Ericzon BG. Liver transplantation for HCV cirrhosis at Karolinska University Hospital Huddinge, Stockholm. Transplant Proc 2006; 38: 2675-86.

5. Warren KS, Rebouças G. Compensated and decompensated ammonia tolerance in hepatosplenic schistosomiasis mansoni. Am J Trop Med Hyg 1966; 1: 32-6.

6. Heathcote EJ. Antiviral therapy: chronic hepatitis C. J Viral Hepat 2007; 14: 82-6.

7. Watanabe A, Okada K, Shimizu Y, et al. Nutritional therapy of chronic hepatitis by whey protein (non-heated). J Med 2000; 31: 283-302.

8. Abi-Nassif S, Mark EJ, Fogel RB, Robert K, Hallisey Jr. Pegylated interferon and ribavirin - induced interstitial pneumonitis with ARDS. Chest 2003; 124: 406-10.

9. Zekri AK, Ashour MS, Hassan A, Alam El-Din H, Shehaby AMR, Abu-Shady MA. Cytokine profile in Egyptian hepatitis C virus genotype- 4 in relation to liver disease progression. World J Gastroenterol 2005; 11: 6624-30.

10. Walzem RL, Dillard CJ, German JB. Whey components: Millennia of evolution create functionalities for mammalian nutrition: What we know and what we may be overlooking. Crit Rev Food Sci Nutr 2002; 42: 353-75.

11. Nozaki A, Tanaka K, Naganuma A, Kato N. Recent advances of basic research and clinical application of lactoferrin as an antiviral reagent against chronic hapatitis C. Nippon Rinsho 2002; 60: 819-29.

12. Ishii K, Takamura N, Shinohara M, et al. Long-term followup of chronic hepatitis $C$ patients treated with oral lactoferrin for 12 months. Hepatol Res 2003; 25: 226-33.

13. Marshall K. Therapeutic applications of whey protein. Altern Med Rev 2004; 9: 136-56.

14. Pugh RN, Murray-Lyon IM, Dawson JL, Pietroni MC, Williams R. Transection of the oesophagus for bleeding oesophageal varices. Br J Surg 1973; 60: 646-9.

15. Paquin P, Lebeuf Y, Richard JP, Kalab M. Microparticulation of milk proteins by high pressure homogenization to produce a fat substitute. Proceedings of the IDF Seminar, Munich Germany 1992; 389-96.

16. El-Sheikh MM, Farrag AF, Shahein NM, El-Shibiny S. Low fat Domiati cheese with particulated whey protein concentrate (PWPC). Egyp J Dairy Sci 2001; 29: 331-42.
17. AOAC. 1990. Official methods of analysis of the Association of Official Analytical Chemists. 15th ed. AVI Publishing Company, Arlington, Virginia, 1990.

18. Ling ER. A text book of dairy chemistry. Vol. II, $3^{\text {rd }}$ ed. Chapman \& Hall Ltd, London, 1963.

19. Barrnett AJG, Tawab A. A rapid method for the determination of lactose in milk and cheese. J Sci Food Agric 1957; 8: 437-41.

20. Chomczyski P, Sachi N. Single step method of RNA isolation by acid guandinium thiocyanate phenol chloroform extraction. Analytical Biochem 1987; 162: 156-9.

21. Matsumoto A, Tanaka E, Suzuki T, Ogata H, Kiyosawa K. Viral and host factors that contribute to efficacy of interferon-alpha 2a therapy in patients with chronic hepatitis C. Digest Dis Sci 1994; 39: 1273-80.

22. Ding Y, Rana RS. Nitric oxide does not initiate but potentiates glucose-induced insulin secretion in pancreatic beta-cells. Biochem Biophys Res Commun 1998; 251: 699-703.

23. Johnson CA, Bass DA, Trillo AA, Snyder MS, De Chatelet LR. Functional and metabolic studies of polymorphonuclear leukocytes in the congenital Pelger-Huet anomaly. Blood 1980; 55: 466-9.

24. Baehner RI, Nathan DG. Quantitative nitroblue tetrazolium test in chronic granulomatous disease. N Engl J Med 1968; 278: 971-6.

25. Thevenot T, Di Martino V, Lunel-Fabiani F, et al. Complementary treatments of chronic viral hepatitis C. Gastroenterol Clin Biol 2006; 30: 197-214.

26. Obeid D, Bauvois B. Interferons: mechanisms, biological activities and survey of their use in human diseases. Current Bioactive Compounds 2006; 4: 431-44.

27. Tanaka K, Ikeda M, Nozaki A, et al. Lactoferrin inhibits hepatitis $C$ virus viremia in patients with chronic hepatitis C: a pilot study. Cancer Sci 1999; 90: 367-71.

28. Anthony JC, Anthony TG, Kimbal SR, Jefferson LS. Signaling pathways involved translational control of protein synthesis in skeletal muscle by leucine. J Nutr 2001; 131: 56S-60S.

29. Granot E, Shouval D, Ashur Y. Cell adhesion molecules and hyaluronic acid as markers of inflammation, fibrosis and response to antiviral therapy in chronic hepatitis C patients. Mediators Inflamm 2001; 10: 253-8.

30. Capra F, Demaria E, Lunardi C. Serum level of soluble intercellular adhesion molecule1 in patients with chronic liver disease related to hepatitis $C$ virus: a prognostic marker for responses to interferon treatment. J Infect Dis 2000; 181: 425-31.

31. Montalto G, Giannitrapani L, Soresi M, et al. Circulating intercellular adhesion molecule-1 in chronic hepatitis C patients with normal or elevated aminotransferase before and after alpha-interferon treatment. Interviol 2006; 46: 35-42.

32. Fan XG, Liu WE, Li CZ, et al. Circulating Th1 and Th2 cytokines in patients with hepatitis $C$ virus infection. Mediators Inflamm 1998; 7: 295-7.

33. Priimägi L, Tefanova V, TalloT, Schmidt E. The role of serum Th1 and Th2 cytokines in patients with chronic hepatitis $B$ and C virus infection. Acta Medica Lituanica 2005; 12: 28-31.

34. Machida K, Cheng KTH, Sung VMH, et al. Hepatitis C virus infection activates the immunologic (Type II) isoform of nitric oxide synthase and thereby enhances DNA damage and mutations of cellular genes. J Virol 2004; 78: 8835-43.

35. Kandemir O, Polat A, Kaya A. Inducible nitric oxide synthase expression in chronic viral hepatitis and its relation with histological severity of disease. J Viral Hepat 2002; 9: 419-23. 
36. Yamaguchi M, Uchida M. Alpha-lactalbumin suppresses interleukin-6 release after intestinal ischemia/reperfusion via nitric oxide in rats. Inflammopharmacol 2007; 15: 43-7.

37. Abdel Fattah S, Abdel Khalik K, El Shawarby L, El Shimi S, Soliman M, Hassan H. Some immunological aspects of chronic liver disease in Egyptian children. J Egypt Soc Parasitol 1991; 21: 343-55.

38. Nakamura I, Ochiai K, Imai Y, Moriyasu F, Imawari M. Restoration of innate host defense responses by oral supplementation of branched-chain amino acids in decompensating cirrhotic patients. Hepatol Res 2007; 37: 1062-7.

39. Omran SA, Zahran NM, El-Kaliouby AH. Cytologic and functional studies of the neutrophil granulocytes in hepatosplenic schistosomiasis. The Egypt J Haemat 1982; 7: 49-54.

40. Ahmad A, Alvarez F. Role of NK and NKT cells in the immunopathogenesis of HCV-induced hepatitis. J Leukoc Biol 2004; 76: 743-59.

41. Konishi M, Iwasa M, Yamauchi K, Sugimoto R, Fujita N, Kobayashi Y. Lactoferrin inhibits lipid peroxidation in patients with chronic hepatitis C. Hepatol Res 2006; 36: 27-32.

42. Crovatto M, Pozzato G, Zorat F, Pussini E, Nascimben F. Peripheral blood neutrophils from hepatitis $C$ virus infected patients are replication sites of the virus. Hematologica 2000; 85: 356-61. 